\title{
Time Dependent Behavior of Soil during Direct Shear Creep
}

\author{
直接せん断クリープにおける土の経時举動
}

Fujiya Komamura*

駒 村 富 士 弥

\section{<要 旨 $>$}

直接せん断方式によるクリープテストを行ない，その結果から土のクリープ挙動（变位〜時間関係）をあらわす方 程式

$$
u=A_{0}+A_{1}\left(1-e^{-\mathrm{ct}}\right)+A_{2} t+A_{3} t^{\alpha}
$$

を導いた。この式は，一次クリープ，二次クリープおよび三次クリープをあらかす項から成り立っているもので，こ れによって, ある限界値以上の応力が作用した場合のクリープのはじまりから破壞にいたるまでの全過程が統一的に 表示できることが示された。

また，作用応力，土の含水比扣よびクリープ曲線の係数 $A_{2}$ (二次クリープ速度）が增加するとクリープ破壊時間が 短くなることがたしかめられ, レートプロセス方程式を応用することによって, 破壊時間〜作用応力〜含水比の関係 式として,

を遒いた。

$$
t_{f}=A^{\prime \prime \prime} \exp \left(\frac{c^{\prime}}{w}\right) \cdot \exp (-m \tau)
$$

\section{Introduction}

Among many landslide occurences some run rapidly while others move slowly. Such difference in characteristics of landslide movement may be explained by the time-dependent properties of soils, since the time-dependent properties of sliding soils appear to play a significant role in the behavior of landslide.

In many soils, continuous application of stresses greater than some critical limiting value may results in an acceleration in the creep rate followed by complete failure. The prediction of time to failure in soil creep appears important in connection with the problem of long term stability of slopes.

In the present study, the direct shear creep test is performed to find a more appropriate equation of creep curve which will be able to describe the creep behavior over any time period. Furthermore, the prediction of time to failure in soil creep is discussed by employing the rate process equation since the rate process theory is thought to have the potential for providing a powerful tool for the description and prediction of soil behavior.

\section{Test Program}

Sample. Sample tested in this investigation was obtained from Ajimame landslide, Nagano Prefecture. Physical properties of the soil are described in Table 1.

Specimens. Specimens were selected from air dry materials passing a $0.42 \mathrm{~mm}$ sieve. Each specimen was brought to a selected water content and compacted in a $5 \mathrm{~cm}$ inside diameter, $12.5 \mathrm{~cm}$ long plastic pipe which can be separated into two parts of top and bottom at center

Table 1 Properties of Soil

\begin{tabular}{lc}
\hline \hline Specific gravity & 2.68 \\
liquid limit & $57.90 \%$ \\
plastic limit & $29.20 \%$ \\
plasticity index & $28.70 \%$ \\
type of soil classified & \\
by U.C. system & $\mathrm{OH}$ \\
\hline
\end{tabular}




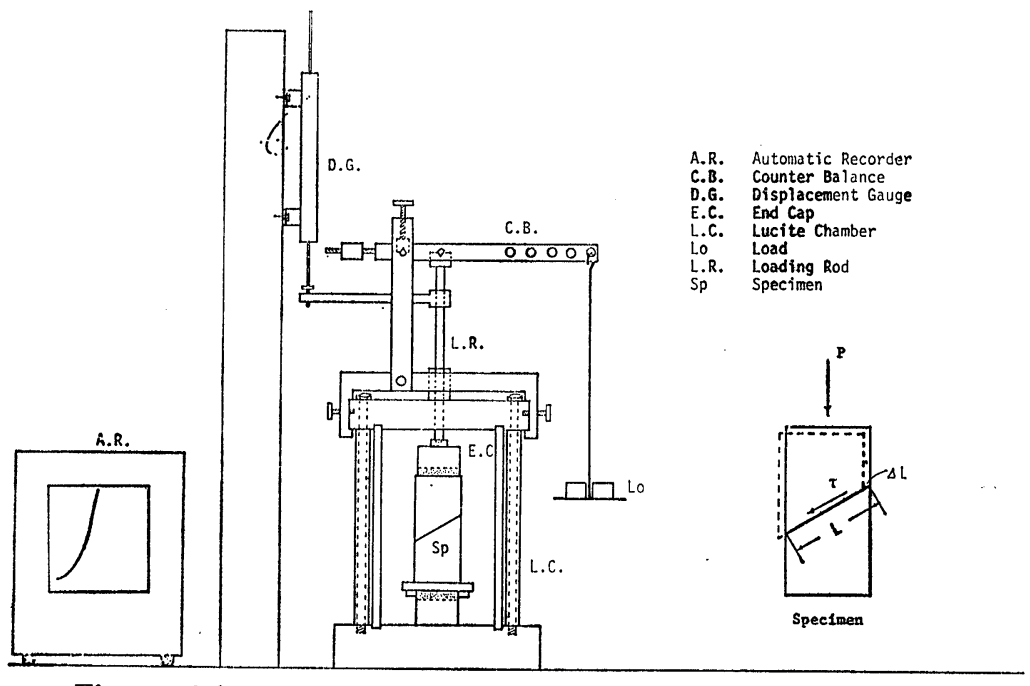

Fig. 1 Schematic Diagram of Creep Test Apparatus and Stress \& Displacement in Specimen

with the bevel of 30 degree, and is used as a jacket of specimen. The specimen was shared in four layers and each layer was compacted by a calibrated hammer of 25 blows. The plastic pipe is hold by wooden framework to make specimen without rupture during the work of arranging specimens.

Apparatus and Method. The test were performed using a triaxial compression test apparatus. A schematic diagram, Fig. 1 shows the detail of the apparatus and its measuring system.

Constant load are applied to the specimen top cap by a cantilever loading frame through a stainless steel loading rod, (L. R.) until the specimen fails. An I. D. S. displacement gauge (D. G. ) is used to measure the displacement of a horizontal bar which is clamped to the loading rod. The amount of displacement measured in gauge is electronically registered on an automatic $\mathrm{X}-\mathrm{Y}$ recorder. (A. R.)

The creep tests were performed by direct shear fashion using the sylindrical specimen with oblique shear plane. Loading caused the specimen to creep along the inclined shear surface, which is produced constrainedly by the displacement of the oblique section of the plastic jacket. A specimen is loaded to failure in a few minutes in this creep test.

The shearing stress along the shear surface is calculated from the axial load $P$ and the angle of oblique section $\theta$ as

$$
\tau=\frac{P}{A} \sin \theta \cdot \cos \theta
$$

where, $P=$ axial load, $A=$ area of horizontal section

The oblique angle of the jacket is fixed to 30 degree in this test program. The relative displacement is given by

$$
u=\frac{\Delta L}{L}
$$

where, $L=$ the length of the sliding surface, $\Delta L=$ the amount of displacement.

\section{Analysis of Test Results}

Typical displacement-time relationship obtained from the test results are shown in Fig. 2 (a) $2(\mathrm{f})$. Upon application of load to a soil specimen, a large limited displacement occurs and is followed by a time-dependent deformation. The creep rate $(d u / d t)$ decreases continuously with time but eventually approaches a steady rate, and continued displacement result in an acceleration of the creep rate and terminates in failure.

A plot of $(d u / d t)$ versus time for creep test at the initial stage of the deformation becomes straight line on semi logarithmic scale and that of the last stage becomes straight line on full 


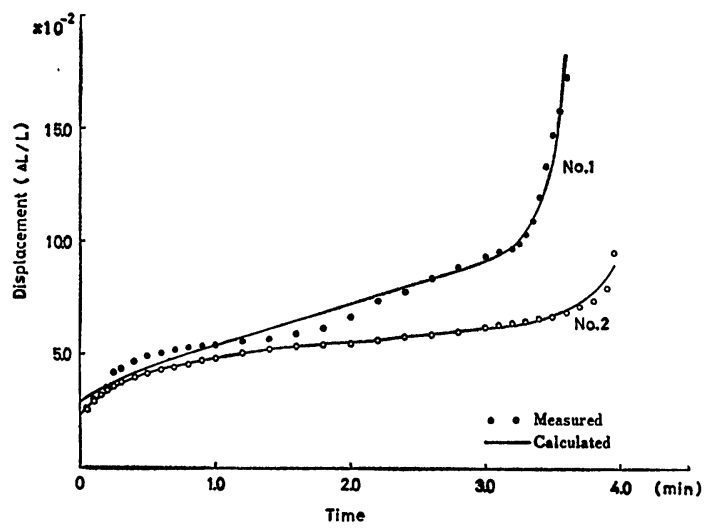

Fig. 2(a) Variation of Displacement with Time

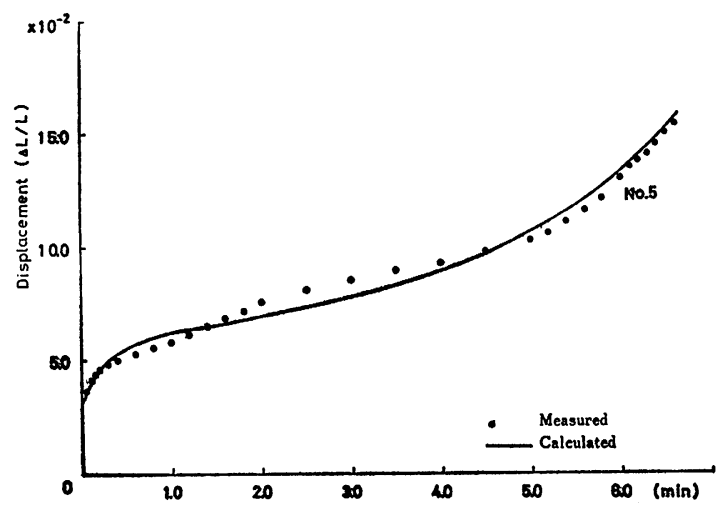

Fig. 2(c) Variation of Displacement with Time

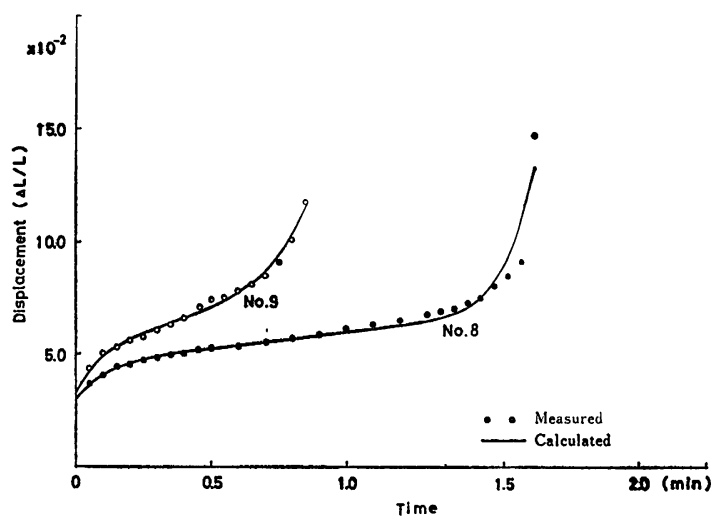

Fig. 2(e) Variation of Displacement with Time

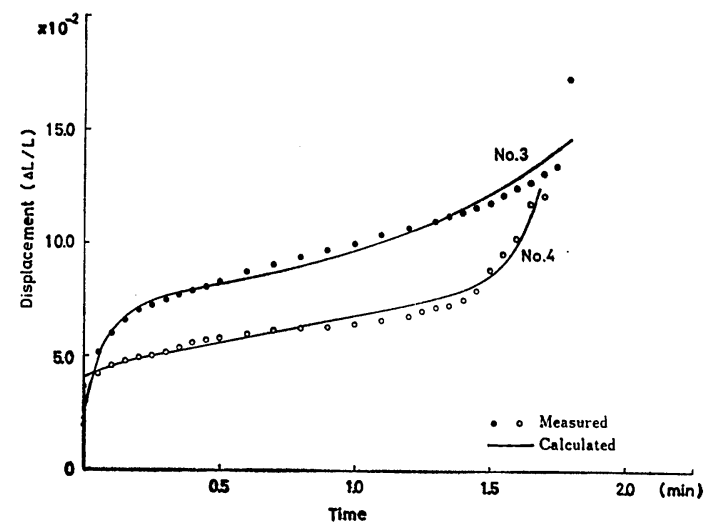

Fig. 2(b) Variation of Displacement with Time

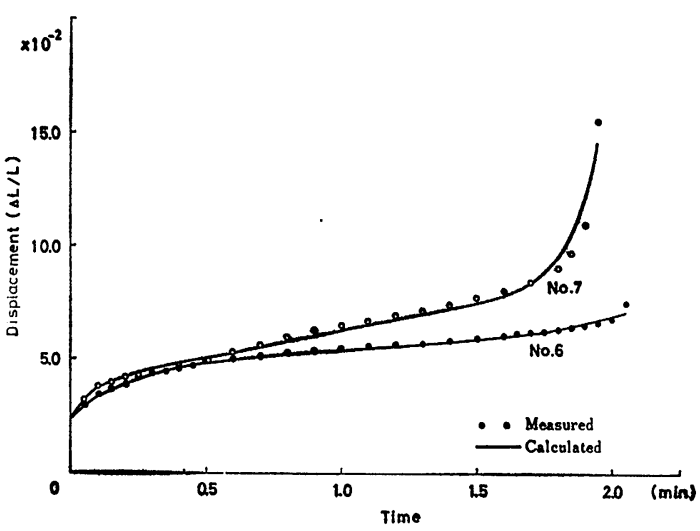

Fig. 2(d) Variation of Displacement with Time

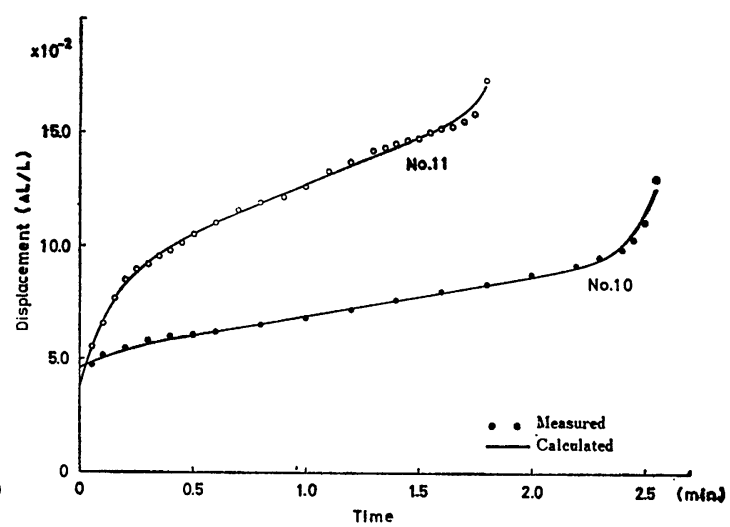

Fig. 2(f) Variation of Displacement with Time

logarithmic scale as seen in Fig. 3 and Fig. 4.

Such variations of creep rate are expressed as

$$
\begin{aligned}
& \frac{d u}{d t}=a_{1} e^{-c t}+a_{2}{ }^{\prime} \\
& \frac{d u}{d t}=a_{2}^{\prime \prime} \ldots \ldots \ldots . . \\
& \frac{d u}{d t}=a_{2}^{\prime \prime \prime}+a_{3} t^{n}
\end{aligned}
$$

Accordingly, the creep rate during the whole period of the deformation may be 


$$
\frac{d u}{d t}=a_{1} e^{-c t}+a_{2}+a_{3} t^{\prime \prime c o}
$$

By integrating the equation (4) with initial condition of $u=0$, at $t=0$, the curve expressing the relationship between the displacement $u$ and time $t$ will be

$$
u=\frac{a_{1}}{c}\left(1-e^{-c t}\right)+a_{2} t+\frac{a_{3}}{n+1} t^{n+1}=A_{1}\left(1-e^{-c t}\right)+A_{2} t+A_{3} t^{\alpha}
$$

To account for initial elastic deformation, additional term which is independent of time is needed. Then, the complete displacement-time equation for soil creep is derived as

$$
u=A_{0}+A_{1}\left(1-e^{-c t}\right)+A_{2} t+A_{3} t^{\alpha}
$$

The value of the coefficients $A_{0}, A_{1}, A_{2}, A_{3}, c$ and $\alpha$ can be determined by the following procedures.

The value of $c$ is obtainable from the slope of the line expressing the relationship between log $(d u / d t)$ and time $t$ as seen in Fig. 3 The coefficientt $\alpha$ can be calculated from $\alpha=n+1$, in which " $n$ " is the slope of the straight line of $\log (d u / d t)$ versus $\log t$ plot as shown in Fig. 4. After determining the value of $c$ and $\alpha$, we can calculate the value of $\left(1-e^{-c t}\right)$ and $t^{\alpha}$ at each time in. terval.

Let, $\left(1-e^{-c t}\right)=X_{1}, t=X_{2}, t^{\alpha}=X_{3}$, the equation (6) may be $u=A_{0}+A_{1} X_{1}+A_{2} X_{2}+A_{3} X_{3}$

Then, the values of the coufficients $A_{0}, A_{1}, A_{2}$ and $A_{3}$ can be calculated by solving the normal equation (8) which is given by means of the least square method.

$$
\left.\begin{array}{l}
\Sigma u=A_{0} N+A_{1} \Sigma X_{1}+A_{2} \Sigma X_{2}+A_{3} \Sigma X_{3} \\
\Sigma u X_{1}=A_{0} \Sigma X_{1}+A_{1} \Sigma X_{1}^{2}+A_{2} \Sigma X_{1} X_{2}+A_{3} \Sigma X_{1} X_{3} \\
\Sigma u X_{2}=A_{0} \Sigma X_{2}+A_{1} \Sigma X_{1} X_{2}+A_{2} \Sigma X_{2}^{2}+A_{3} \Sigma X_{2} X_{3} \\
\Sigma u X_{3}=A_{0} \Sigma X_{3}+A_{1} \Sigma X_{1} X_{3}+A_{2} \Sigma X_{2} X_{3}+A_{3} \Sigma X_{3}^{2}
\end{array}\right\}
$$

According to the above analysis, the coefficients of creep curve for the soil specimens are obtained as shown in Table 2.

Fig. 2 shows the computed and measured creep curve of specimens. It can be seen from the figure that the agreement between the two curves is generally good.

Three different stages at creep behavior called primary creep (transient creep), secondary creep (steady creep) and tertiary creep (failure creep) are also explained by equation (6). The first two terms in right hand member of equation (6) express the primary creep, third term expresses the secondary and the fourth expresses the tertiary creep.

The typical creep curves for these three stages of creep are illustrated in Fig. 5

The creep behaviors for low stress intensities have been examined in the previous studies by the auther. (3), (4).

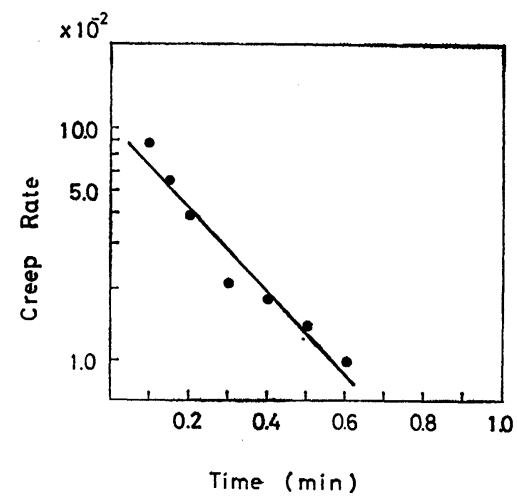

Fig. 3 Plot of Creep Rate vs. Time at Initial Stage of Deformation

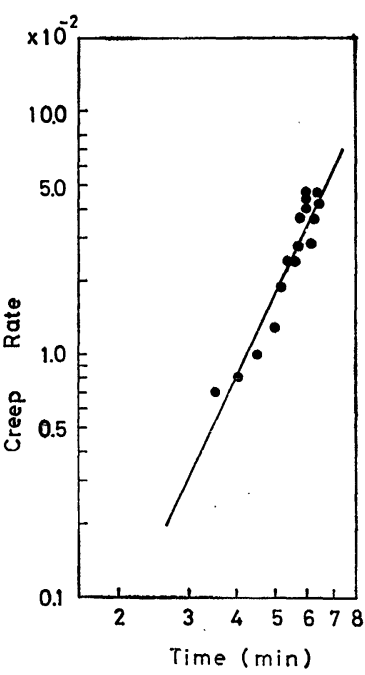

Fig. 4 Plot of Creep Rate vs. Time at Last Stage of Deformation 
地すべク Vol. 17, No.4（1981）

Table 2 Results of Creep Test

\begin{tabular}{|c|c|c|c|c|c|c|c|c|c|c|}
\hline \multirow{2}{*}{$\begin{array}{l}\text { Specimen } \\
\text { number }\end{array}$} & \multirow{2}{*}{$\begin{array}{c}\text { stress } \\
\tau\left(\mathrm{kg} / \mathrm{cm}^{2}\right)\end{array}$} & \multirow{2}{*}{$\begin{array}{l}\begin{array}{l}\text { water } \\
\text { content }\end{array} \\
\omega(\%)\end{array}$} & \multirow{2}{*}{$\begin{array}{l}\text { time to } \\
\text { failure }\end{array}$} & \multicolumn{6}{|c|}{ coefficients } & \multirow{2}{*}{\begin{tabular}{|c|}
$\begin{array}{c}\text { shear } \\
\text { modulus }\end{array}$ \\
$G_{0}\left(\mathrm{~kg} / \mathrm{cm}^{2}\right)$
\end{tabular}} \\
\hline & & & & $C$ & $\alpha$ & $A_{0}$ & $A_{1}$ & $A_{2}$ & $A_{3}$ & \\
\hline 1 & 0.20 & 44.9 & 36.0 & 3,290 & 26,108 & 2. $929 \times 10^{-2}$ & $0.677 \times 10^{-2}$ & $1.811 \times 10^{-2}$ & 2. $42 \times 10^{-16}$ & 6. 83 \\
\hline 2 & 0.20 & 47.1 & 3. 95 & 2,641 & 15,030 & 2. $419 \times 10^{-2}$ & 2. $051 \times 10^{-2}$ & $0.536 \times 10^{-2}$ & $2.48 \times 10^{-11}$ & 8.27 \\
\hline 3 & 0.22 & 46.3 & 1.80 & 12,139 & 3,286 & 2. $802 \times 10^{-2}$ & 4. $459 \times 10^{-2}$ & $1.798 \times 10^{-2}$ & $6.05 \times 10^{-3}$ & 7.85 \\
\hline 4 & 0.22 & 46.7 & 1.70 & 8,731 & 16,279 & 4. $126 \times 10^{-2}$ & $0.346 \times 10^{-2}$ & 2. $334 \times 10^{-2}$ & 8. $55 \times 10^{-6}$ & 5. 33 \\
\hline 5 & 0.24 & 42.9 & 6.65 & 3,956 & 4,446 & 3. $130 \times 10^{-2}$ & 2. $448 \times 10^{-2}$ & $0.688 \times 10^{-2}$ & 1. $25 \times 10^{-5}$ & 7.67 \\
\hline 6 & 0.24 & 46.2 & 2. 06 & 5,079 & 5,157 & 2. $328 \times 10^{-2}$ & 2. $358 \times 10^{-2}$ & $0.695 \times 10^{-2}$ & 2. $41 \times 10^{-4}$ & 10.31 \\
\hline 7 & 0.26 & 42.6 & 1.96 & 12,065 & 19,217 & 2. $375 \times 10^{-2}$ & 1. $541 \times 10^{-2}$ & 2. $351 \times 10^{-2}$ & $1.61 \times 10^{-7}$ & 10.94 \\
\hline 8 & 0.29 & 43.9 & 1.67 & 8,711 & 15,292 & 3. $023 \times 10^{-2}$ & 1. $598 \times 10^{-2}$ & 1. $324 \times 10^{-2}$ & $1.91 \times 10^{-5}$ & 9.59 \\
\hline 9 & 0.31 & 42.5 & 0.88 & 14,251 & 6,592 & 3. $285 \times 10^{-2}$ & 1. $650 \times 0^{-2}$ & 4. $121 \times 10^{-2}$ & 8. $955 \times 10^{-2}$ & 9.43 \\
\hline 10 & 0.31 & 44.0 & 2.55 & 5,079 & 23,570 & 4. $592 \times 10^{-2}$ & $0.716 \times 10^{-2}$ & 1. $644 \times 10^{-2}$ & 8. $35 \times 10^{-12}$ & 6.75 \\
\hline 11 & 0.33 & 41.9 & 1.81 & 7,212 & 27,538 & 3. $890 \times 10^{-2}$ & $4.709 \times 10^{-2}$ & 4. $108 \times 10^{-2}$ & 9. $80 \times 10^{-10}$ & 8.48 \\
\hline
\end{tabular}

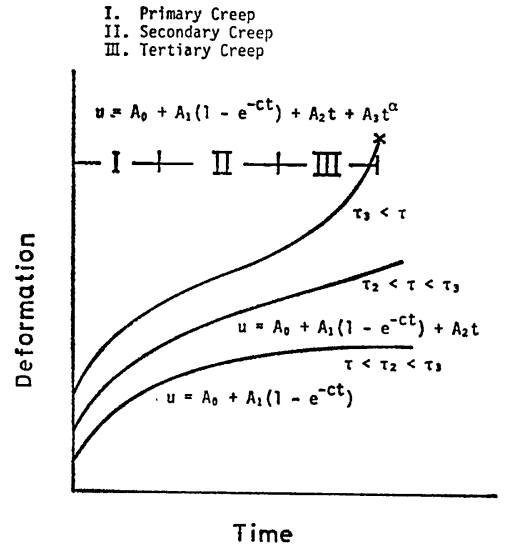

Fig. 5 Typical Creep Curve for Different stress Level

\section{Prediction of Time to Creep Failure}

It is confermed from the creep test that soils may fail under a sustained stress greater than some limiting value below which failure does not develope. The time to failure in soil creep may be predicted by employing the theory of rate process.

The rate process theory has been used by several investigators to describe the creep behavior of soils under stress. For example, Murayama and Shibata (7) make use of rate process theory to assign a viscosity to the dashpot in their rheological model. Mitchell et. al., (5) have used the theory of rate process to develope a certain rate equation for creep of soil, directly from considerations of micro scale deforma tions, without using rheological model.

The rate process theory is generally expressed by the equation proposed by Tobolsky and Eyring(1).

$$
\frac{d r}{d t}=2 D \cdot \frac{K T}{h} \exp \left(-\frac{\Delta F}{R T}\right) \cdot \sinh \left(\frac{\lambda \tau}{2 K T}\right)
$$

in which, $r=$ shear strain, $t=$ time, $D=$ a constant depending upon the material structure, $h=$ Plank's constant, $K=$ Boltzman's constant $R=$ gas constant, $T=$ absolute temperature, $F=$ free energy of activation, $\lambda=$ an average distance between successive equilibrium position.

Equation (9) may be rewritten in a more condenced form as

$$
\frac{d r}{d t}=C \cdot \sinh (B \tau)
$$

where, $B=\frac{\lambda}{2 K T}, C=2 D \cdot \frac{K T}{h} \cdot \exp \left(-\frac{\Delta F}{R T}\right)$

From the results of the creep test, the relationship between the value of $\sinh (B \cdot)$ and strain rate of secondary creep of soil specimens with water content of narrow range of variation which are regarded as nearly constant is examined to be straight line on full logarithmic scale. As can be seen in Fig. 6, the straight line is

$$
A_{2}=\left(\frac{d r}{d t}\right)_{\mathbb{I}}=C\{\sinh (B \tau)\}^{p}
$$

where, $p=\mathbf{a}$ coefficient

Moreover, the results of the creep test show that the relationship between the time to creep failure and the coefficient $A_{2}$ which correspond to the strain rate of secondary creep is plotted on 


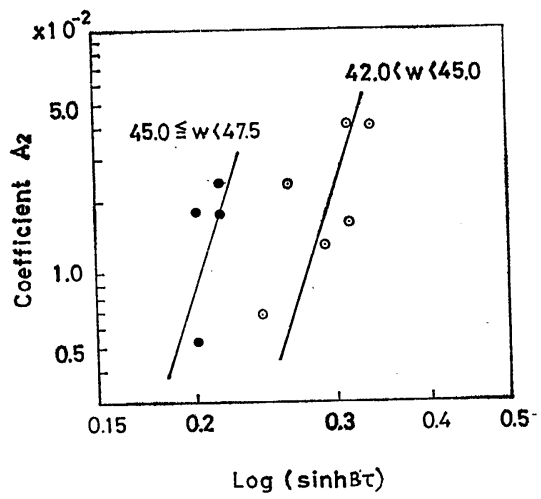

Fig. 6 Relationship between $\sinh (B \tau)$ and Coefficient $\mathrm{A}_{2}$

straight line in logarithmic scale of Fig. 7 as was pointed out by Saito (9). This straight line is

$$
\log t_{f}=\log b-k \cdot \log A_{2}
$$

or

$$
t_{f}=b \cdot\left(\frac{d r}{d t}\right)_{\mathbb{1}}^{-k}
$$

Equation (13) indicates that the time to creep failure is related closely to the strain rate of secondary creep, and it can be recognized that the larger the value of coefficient $A_{2}$ in equation (12) is, the shorter the time to failure in soil creep will be.

Substituting equation (11) into (13), the time to creep failure is given as a function of $\sinh (B \tau)$.

$$
t_{f}=A^{\prime}\{\sinh (B \tau)\}^{-k p}=A^{\prime}\{\sinh (B \tau)\}^{-q}
$$

Since $A^{\prime}$ becomes a function of $\exp \{k \cdot(\Delta F) / R T\}$, equation (13) may be rewritten as

$$
t_{f}=A^{\prime \prime} \cdot \exp \left\{\frac{k(\Delta F)}{R T}\right\}\{\sinh (B \tau)\}^{-}
$$

This equation indicates that an increase in temperature decreases the time to creep failure. The effects of the temperature for the behavior of soils are reported by Mitchell (6) that an increase in temperature decreases modulus of elasticity and effective stress.

The behavior of landslide may be affected by water content of the soil rather than temperature.

The relationship between shear modulus $G_{0}\left(=\frac{\tau}{A_{0}}\right)$ and water content $w$ is examined by the test results as shown in Fig. 8, and the equation for this relationship is derived as

$$
G_{0}=G_{0}{ }^{\prime} \exp \left(\frac{c^{\prime}}{w}\right)
$$

where, $c^{\prime}=$ a coefficient

This suggest that an increase in water content causes an decrease in shear modulus.

The function $\exp \left(c^{\prime} / w\right)$ is thought to indicate that an increase in water content has a similar effect to the temperature for the activation of soil particles and time to creep failure. In order to express the role of water content in the equation for soil creep, the function exp $\left(c^{\prime} / w\right)$ may be useful. Accordingly, the equation for the prediction of time to creep failure may be rewritten as equation (17), substituting the function $\exp \left(c^{\prime} / w\right)$ in place of the function $\exp \{k(\Delta F) / R T\}$ 
in equation (15).

$$
t_{f}=A^{\prime \prime} \exp \left(\frac{c^{\prime}}{w}\right)\{\sinh (B \tau)\}^{-q}
$$

Equation (17) may be rewritten more simple form in accordance with the magnitude of shear stress.

As the value of $(B \tau)$ will generally greater than 1 for stresses sufficient to cause significant creep deformation in most soils, then

$$
\sinh (B \tau) \fallingdotseq \frac{1}{2} \exp (B \tau)
$$

and equation (17) becomes

$$
t_{f}=A^{\prime \prime \prime} \exp \left(\frac{c^{\prime}}{w}\right) \cdot \exp (-m \tau)
$$

where, $m=q^{B}$

This equation and test results show that the time to creep failure under a sustained stress decrease with increase in water content and stress level.

The values of the coefficients $A^{\prime \prime \prime}, c$ and $m$ in equation (19) can be obtained by means of the least square

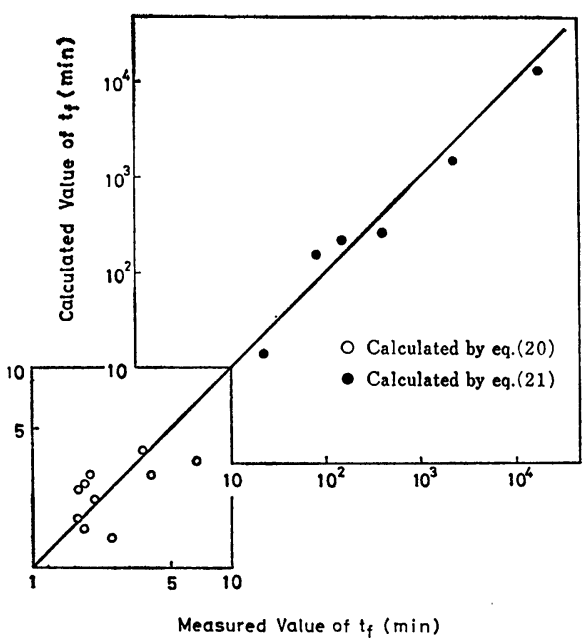

Fig. 9 Comparison of Observed and Calculated Values of Time to Creep Failure method using creep rupture test results. Accrding to the calculation from the test results which is described in Table 2 the time to creep failure of specimens are expressed as

$$
t_{f}=6.142 \times 10^{-2} \exp \left(\frac{2.795 \times 10^{2}}{w}\right) \cdot \exp (-10.432 \tau)
$$

where, $w=$ water content $(40 \%-50 \%)$.

The similar relationship among time to creep failure, deviator stress and water content of soil is developed as equation (21) according to the data of undrained triaxial creep rupture test performed by Murayama, Kurihara and Sekiguchi. (8)

$$
t_{f}=5.326 \times 10^{-7} \exp \left(\frac{2.038 \times 10^{3}}{w}\right) \cdot \exp (-7.790 \sigma)
$$

where, $\sigma=\sigma_{1}-\sigma_{3}, w=$ water content $(50 \%-55 \%)$.

Comparison between observed time to creep failure and calculated values by equation (20) and (21) is shown in Fig. 9.

\section{Summary and Conclusions}

In this investigation, a displacement-time equation which is considered to be valid to describe the creep behavior of sliding soil under various stress conditions has been proposed and an equation for prediction of time to creep failure is derived by applying the results of the creep test and the theory of rate process.

For stresses greater than some critical limiting value, the deformation of soil starts from primary creep, and after passing the stage of secondary creep, during which the displacement increase with constant rate, continued displacement result in an acceleration of the creep rate and terminates in failure. This creep behavior of soil is expressed by a displacement-time equation derived as

$$
u=A_{0}+A_{1}\left(1-e^{-c t}\right)+A_{2} t+A_{3} t^{\alpha}
$$

It is confermed experimentally that the time to creep failure under a sustained stress decrease with increase in water content and stress level. Applying the experimental results to the rate process equation for the deformation of the materials, the equation for the prediction of time to creep failure of soils has been derived as the function of stress and water content.

$$
t_{f}=A^{\prime \prime \prime} \cdot \exp \left(\frac{c^{\prime}}{w}\right) \cdot \exp (-m \tau)
$$

\section{REFERENCES}

1. Eyring, H. :Plasticity, and Diffusion as Examples of Absolute Reaction Rates, Journal of Chemical Physics, 
Vol. 4, No., 1936.

2. Garofalo, S. : Fundamentals of Creep and Creep-Rupture in Metals, McGraw-Hill, 1965.

3. Komamura, F. and Huang, R. : New Rheological Model for Soil Behavior, Journal of the Geotechnical Engineering Division, ASCE, Vol. 100, No. GT. 7, 1974.

4. Komamura, F. : Rheological Studies on the Behavior of Landslide, The Bulletin of the Faculty of Agricalture, Mie University, No. 53, 1976.

5. Mitchell, J.K. et al. : Soil Creep as a Rate Process, Journal of Soil Mechanics and Foundation Engineering, ASCE, Vol. 94, No. SM. 1, 1968.

6. Mitchell, J. K. : Fundamentals of Soil Behavior, Wiely, 1976.

7. Murayama. S. and Shibata, T. : On the Rheological Characters of Clay, Transactions of the Japan Society of Civil Engineers, No. 40, 1956.

8. Murayama, S., Kurihara, N. and Sekiguchi, H. : On Creep Rupture of Normally Consolidated Clays, Annuals, 13B, Disaster Prevention Research Institute, Kyoto University, 1970.

9. Saito, M. and Uezawa, H. : Forcasting the Time of Occurrence of A Slope Failure, Journal of the Japan Society of Landslide, Vol. 2, No. 21966.

10. Schiffman, R. L.: The Use of Visco-Elastic Stress Strain Laws in Soil Testing, ASTM. Spec. Tech. Pub. No. 254, 1959.

11. Yamada, G. et al. : Rupture of Takabayama Tunnel by Landslide, Journal of the Japan Society of Landslide, Vol. 8, No. 1, 1971.

（原稿受理日 昭和55年10月 5 日）

\section{北海道地すべり分布図}

\section{地すべり学会北海道支部}

北海道支部のご努力により本図書の上梓をみることが できた。内容は(1)約 6,600 力所の地すべりの位置と(2)主 要地すべり 432 力所の位置および関連事項を記載してい る。

(1) 地すべりは, 公刊資料と聴きこみ調查によった。

(2) 主要地すべりは，1973年の「日本の地すべり」（建 設省砂防課・林野庁治山課・構造改善局資源課）を参 考に地すべり防止区域等を加光て, 規模・地質・保全 対象その他の摘要事項を記载したものである。

地すべり分布図は従来からもいろいろ発表されていた が，5 万分の 1 地形図を基図（0.6 倍縮小印刷）にした 本書は, 種々の土地利用の事前調査に極めて利用度の高 い情報を提供している。地質については北海道開発庁, 工業技術院地質調査所括よび道立地下資源調查所によ。 て 5 万分の 1 図幅調查が精力的に行われた時期があり, 内地よりも高い密度で地質図が刊行されている。こうし た地道な調查が本書のような見事な成果を可能としたの であろう。
体裁怙よび内容は，次のと捛りである。

主要地すべり一覧表 : 名称・規模・種類・活動状況 ·地質 ·災害・保全対策等を記述

総括図: 20 万分の 1 地勢図 27 葉怙よび 60 万分の 1 図 上に地すべり（白炇き朱円印）と主要地すべり(べ タ朱丸印）の位置を表示

地すべり分布図：5 万分の 1 地形図 266 葉に地すへ

りと主要地すべりの位置・形態を表示

その他, 国有林・道有林・大学演習林ならびに参考文 献も示している。な拈，60万分の 1 図のみの入手も可能 である。

\section{発行日 1980 年11月10日 \\ 発行元 （社）北海道治山協会 \\ 厂 060 札幌市中央区北 4 条西 4 丁目 （林業会館内）}

Tel：(011)251-4151 内線 65 


\section{長野県下伊那郡大鹿村小塩沢地すべりについて \\ 「地すへり」Vol. 17, No. 4 (通巻第64号) 1981年（昭和56年）3月 \\ 北沢 秋司}

これまでの調査によって，この地すべりの特徵及び対策を，次のようにまとめることができる。

（1）三波川帯結晶片岩類の破砕が著しい地帯に発生していて，地すべり形態が不完全で，地すへりり性崩壊に類 別される。

（2）断層によって分断されたブロック内に発生しているもので，ここはまた古い地すべり地形である。

（3）基盤に漫透した地下水によって，破砕部が膨潤化して，それが表面に突出して，滑落崖を形成した。

(4) 滑落崖は, 蛇紋岩の貫入部で, このような弱線部が 2 本ある。

（5）小塩沢に施工した，床固工及び谷止工によって，渓床が上昇し，地すべり地内に地下水を漫透させた。

（6）対策としては，主として地すべり地頭部の地下水の排除に重点を置くことが望ましい。

新潟県東山背斜の地すべりとテクトトープ

「地すべり」Vol. 17, No.4（通巻第64号）1981年（昭和56年）3月

寺川 俊浩, 和久 紀生, 西田 彰一

小論は，新潟県東山油田に発達する東山背斜帯に分布する地すべり発生の素因と機構に関する構造地質学的考 察を行なったものである。東山韭斜は北の部分では非対称的背斜を形成し, 西翼の傾斜は急, 東翼は緩く, 地す ベりは東翼部に多発している。この傾向は岩質（物理的・化学的性質）が内的原因となるものである。これに対 し，背斜南部では対称的急傾斜の背斜となり，地すべりは背斜軸部（頂部）に集中して発生する。これは持そら く軸部の断裂による破砕が起因となるものであろう。つまり，背斜北部は岩質性地すべり，南部は構造性地すべ りに区分できるように，この地带の地すべりは同一系列の背斜にありながら，その類型は個々の構造単元の性格 に規制されている。

Time Dependent Behavior of Soil during Direct Shear Creep

「地すへり」Vol. 17，No.4（通巻第64号）1981年（昭和56年）3月

\section{Fujiya Комамura}

An equation for creep curve which can be used to characterize the creep behavior of soils is derived from creep test results. The equation which consists of the terms expressing the primary creep, secondary creep and tertiary creep is valid to describe the creep behavior over any time period.

The time to creep failure under a sustained stress decrease with increase in water content and stress level. The prediction of time to failure in soil creep was discussed by applying the displacement-time equation and the theory of rate process. The equation for prediction of creep failure of soil is derived as a negative exponential function of stress and water content.

新潟県の地すべりと地質および地質構造の関係 (2)

「地すべり」Vol. 17，No.4（通巻第64号）1981年（昭和56年）3月

福本 安正

崖崩れによる家屋被害に関する調查研究

「地すへり」Vol. 17, No. 4 (通巻第64巻) 1981年（昭和56年）3月

鵜飼 恵三, 石橋 正司, 竹洞 一則

昭和53年 6 月の新潟水害時に発生した崖崩れによる家屋被害に関し，その原因の究明及び防止対策の立案の一 助となることを目的として, 調查研究を行なった。調查は独自に作成した調査表にもとづき, 一つ一つの崖崩れ について聞き込み及び現場調査を行なった。この結果, 崖崩れの多くには崩壞前に前兆現象が見られたこと, 家 屋の大部分は敷地内で切土の崖に接近して建てられていること, 過去に崩壊の経歷がある崖では少ない降雨量で 崖崩れが発生していることなどが明らかになった。 